\title{
PORTRAYAL OF THE AMERICAN CULTURE THROUGH METAFICTION
}

\author{
Abdolrazagh Babaei \\ abdorrazzaqbabaei@gmail.com \\ Universiti Putra Malaysia \\ AMIN TAADOLKHAH \\ ataadolkhah@yahoo.com \\ Tehran Markaz Azad University, \\ Iran
}

\begin{abstract}
Kurt Vonnegut's position that artists should be treasured as alarm systems and as biological agents of change comes most pertinent in his two great novels. The selected English novels of the past century - Cat's Cradle (1963), Slaughterhouse Five (1969), and Breakfast of Champions (1973) - connect the world of fiction to the harsh realities of the world via creative metafictional strategies, making literature an alarm coated with the comforting lies of storytelling.

It is metafiction that enables Vonnegut to create different understandings of historical events by writing a kind of literature that combines facts and fiction. Defined as a kind of narrative that "self-consciously and systematically draws attention to its status as artefact" metafiction stands against the duplicitous "suspension of disbelief" that is simply an imitation and interpretation of presumed realities. As a postmodern mode of writing it opts for an undisguised narration that undermines not only the author's univocal control over fiction but also challenges the established understanding of the ideas. Multidimensional display of events and thoughts by Vonnegut works in direction of metafiction to give readers a self-conscious awareness of what they read.

Hiroshima bombing in 1946 and the destruction of Dresden in Germany by allied forces in World War II are the subjects of the selected novels respectively. In them Vonnegut presents a creative account in the form of playful fictions. The study aims to investigate how the novelist portrayed human mentality of the American culture by telling self-referential stories that focus on two historical events and some prevailing cultural problems.
\end{abstract}

Key words: Artefact, American Culture, Metafiction, Self-consciousness, grand narratives.

\section{INTRODUCTION}

"Everything is framed, whether in life or in novels" (Waugh, 1984, p. 28).

This sentence may get us to the core of the metafictional discourse as presented by Patricia Waugh in her classic book Metafiction: The Theory and Practice of Self-Conscious Fiction. She gives some definitions from Oxford English Dictionary for the word "frame" to expand her discussion of metafiction and frame-breaking. A frame, to her, may be defined as "construction, constitution, build; established order, plan, system [...] underlying support or essential substructure of anything" 
(Waugh, 1984, p. 28). By frame and frame-breaking theory metafiction begins with the impression that both what people know as real world and the world of fiction are structured and perceived through frames. Contemporary metafiction is a part of postmodernist literature; that is why it finds it interesting to foreground framing as a revealing notion in translating the complex debates on the nature and existence of reality by turning to narrative's fictional structure.

Metafiction seeks the solution to this never ending dispute in turning inwards to examine the fundamental structures of narrative fiction in order to study the relationship between fictional and cultural frames. Practitioners of this mode of writing by questioning the conventional frames of narrative writing offer analogous models for understanding the world as framed constructions. In Vonnegut's novel, Slaughterhouse-Five, for instance, violating the traditional form of historical writing by an author who is himself the witness of his story provides readers with a new insight about the artificial nature of archival history to which Waugh refers to as "artifice, a web of interdependent semiotic systems"(Waugh 1984, p. 9). The paper, then, aims at displaying the way writers of metafiction in general and Vonnegut in particular show an understanding of the construction of grand narratives of history, religion, and art in the world outside novels. Societies' understanding of phenomena like history, religion, and art constructs a wider field of standards known as culture. The term culture, derived from the Latin word cultura or cultivation, first appeared in its current sense in Europe in the 18th and 19th centuries to denote a process of improvement or cultivation in agriculture and horticulture (Harper, 2001). The betterment or refinement of the individual through education, the fulfilment of national aspirations, and a universal human capacity were further references of the term in the 19th century. Furthermore, George Simmel defines culture as "the cultivation of individuals through the agency of external forms which have been objectified in the course of history" (Levine, 1971, p.6). The definitions of the term "culture", in many ways, relate to what metafiction is trying to show by revealing the constructedness of human ideas through its new medium. The understanding of the so-called fundamental ideas is what this new medium lays bare by the truth that "we are all trapped in our systems for measuring and understanding the world" (Forrest, 1973, p. 4).

\section{METAFICTION}

Although the term was coined by the American critic William Gass in 1970, metafiction has been defined best by Patricia Waugh. To her "metafiction is a term given to fictional writing which self-consciously and systematically draws attention to its status as an artefact in order to pose questions about the relationship between fiction and reality". By employing a variety of metafictional procedures the writings of metafiction "[...] not only examine the fundamental structures of narrative fiction, they also explore the possible fictionality of the world outside the literary fictional text (Waugh, 1984, p. 2).

Linda Hutcheon, a significant figure of metafictional criticism, in Narcissistic Narrative: The Metafictional Paradox claims that metafiction does have a social side as it obviously establishes links with reality. Her emphasis on the social role of me- 
tafiction is to the extent that she argues: "If self-reflecting texts can actually lure the reader into participating in the creation of a novelistic universe, perhaps he can also be seduced into action--even direct political action (Hutcheon ,1980, p. 155). Self-reflexive reflective, self-conscious literature, as other names for metafiction, appear significantly in the works of postmodern writers such as Vladimir Nabokov, John Fowles, B. S. Johnson, Donald Barthelme, John Barth, Jorge Luis Borges, Julian Barnes, and finally Kurt Vonnegut. The prevalence of metafiction in the 20th century, as well, relates to some social and cultural aspects of the age. To Waugh the present increased interest in new modes of fiction that insist on consciousness "is partly a consequence of an increased social and cultural self-consciousness" (Waugh, 1984, p. 12). In metafiction the impact of the world outside the text, therefore, would find footsteps in the creative product, because the fiction and the culture out of which that fiction arises are in a mutual interaction in showing the level of self-consciousness.

In the works of the aforementioned authors playing with the conventions of the novel leads to a kind of narrative that reveal its status as an artefact to expose the hidden layers of grand narratives of the age. Reading Vonnegut's metafictions generates a discussion on the thematic and structural strategies used in the novels to achieve the tenets of metafictional discourse. As the first element of any definition of metafiction, self-consciousness builds the most important theme of Vonnegut's writing. It is metafiction that helps him to expose the concealed aspects of the grand narratives of American culture, history or religion, by putting it in a fictional setting. By metafiction Vonnegut, in fact, conceptualizes history, for instance, to recreate a new understanding of the notion by displaying it as a constructed reality the same as fiction.

\section{VONNEGUT'S METAFICTION}

Exposure in metafiction equals with the term "decoding" by which the paper studies some social structures Vonnegut puts into consideration in his novels. Whether to call it exposing or decoding, Vonnegut does not hide that he uses his art as an affective medium. In the interview with Playboy printed in Conversations with Kurt Vonnegut, he explains: "My motives are political. I agree with Stalin and Hitler and Mussolini that the writer should serve his society. I differ with dictators as to how writers should serve. Mainly, I think they should be -- and biologically have to be - agents of change. For the better, we hope" (Allen, 1993, p. 76). The way he affects his society is as sincere as he talks about his duties in art. His metafiction is much more different from his counterparts who walk at the cutting edge of postmodern literature haunted by the representation and form rather than themes.

Kurt Vonnegut is perhaps the most popular and widely read American novelist of the past century who was continually challenging the narrative strategies/ tactics in his works. He has specifically examined the potential of fiction to reach an acceptable literary method of presenting his ideas which he willingly calls a part of his commitment and responsibility to his readers. This sense of duty leads Vonnegut to change the way people perceive reality by his matchless way that 
stands against the conventional style of "old-fashioned storytellers" (Vonnegut, 1973, p. 209). Exposing the conventions of realism, Vonnegut's metafiction may carry thematic points without didactic authorial intrusion.

Cat's Cradle (1963) is not the first practice of the metafictional techniques for Vonnegut but it is his first serious and successful experience of its kind. In Mother Night (1961) Vonnegut uses the double agent Howard Campbell as the narrator and also reminds readers of himself as the omniscient author behind the narrator "I". Mother Night as the confessions of Campbell has an "Editor's Note", the same as in Cat's Cradle, with an epigraph before the first page of the story addressing readers. It declares that Vonnegut is the author and editor of the narrator's autobiography. In the "Editor's Note" Vonnegut, playing the role of the editor, warns about the misleading aspects of the confessions of Howard Campbell as an artist, because he has to lie for "the demands of art alone" (Vonnegut, 1963, p. ix). This is the first direct statement of Vonnegut about literature in his work and it starts a series of works known as metafiction with a common thematic and formal progression which present an increasing self-consciousness that goes on until the publication of Breakfast of Champions in 1973.

To name the most significant examples of Vonnegut's self-conscious novels which directly deal with cultural issues, Cat's Cradle (1963), Slaughterhouse-Five (1969), and Breakfast of Champions (1973) stand in the first row. First of all, the three selected novels trace the recognizable progress of a writing maturity in Vonnegu$\mathrm{t}^{\prime} \mathrm{s}$ career beginning with Cat's Cradle as a serious leap of Vonnegut's postmodern metafictions and ending in a literary ascendancy in Breakfast of Champions. Cat's Cradle presents an apocalyptic setting that challenges the grand narrative of 'religion' as a leading factor in human communities, while Slaughterhouse-Five offers a motivating portrayal of 'history' through a supposedly harsh setting of a forgotten modern massacre. Breakfast of Champions, finally, displays a caricature of the follies of American culture in the form of a radical overt metafiction which the writer, Vonnegut, enters as a character and the author.

\section{ANALOGICAL DECODING OF FICTIONAL CONSTRUCTION}

Metafiction intentionally diverts the attention of readers away from mimesis to make them aware of the real existence of fiction as an artistic artifice using frame and frame-breaking, play, authorship, parody, and intertextuality as metafictional devices. In Cat's Cradle Vonnegut for the first time offers a deliberate view of constructedness by subverting the conventions of fiction and self-conscious narration through frame-breaking, play, and authorship. The intrusion of the author, direct comments on writing in the foreword of the novel, the episodic plot structure of the narrative and its multi-chapters, story within story, and playing with the notion of truth by mixing fact and fiction are strategies that sustain the artificiality of Vonnegut's narrative readers.

Slaughterhouse Five (1969) is the story of its writer's effort to fictionalize a modern massacre - thefirebombing of Dresden by allied forces in 1945, witnessed by the real Vonnegut as an American POW. The same as in Cat's Cradle, in Slau- 
ghterhouse-Five Vonnegut begins to play with the structures of narrative showing his opposition to totalizing structures in art and society. While Christina Jarvis in "The Vietnamization of World War II" believes "Vonnegut's Primary goal (in Slaughterhouse-Five) is a specific revision of World War II narratives" (Bloom, 2009, p. 63), this study claims that he targets spheres much broader than what Jarvis has determined. Autobiographic introduction, coexistence of the real, the fictional, and the fantastic space, authorial intrusion, presenting an author-narrator, putting surrogate author in the story, and finally intertextuality constitute the metafictionality of the novel. They provoke readers to think about what they are reading instead of accepting it as reality. Revealing the constructedness of the novel is the first step in conceptualizing the world as a set of constructions made by the men like the creator of these novels. History is a grand narrative and the novel aims at depicting its artificial aspects by means of self-conscious strategies.

The third selected novel, Breakfast of champions, the most overtly metafictive book of the novelist, because it progresses to the point of the presence of the real author in the novel talking with the surrogate author and setting him free at the final stage. In fact, Vonnegut's seventh novel, published in 1973, closes a self-conscious artistic journey he started in Mother Night (1962), developed in Cat's Cradle (1963), and climaxed to make a masterpiece in Slaughterhouse-Five (1969). The novel starts with a lengthy preface in which Vonnegut explains the title of the novel, discusses writing novels, and also offers a clear description of his transformed writing style. All this happens in twenty four chapters of the novel that ends with an epilogue. The preface and epilogue in Breakfast of Champions works like the first chapter of Slaughterhouse-Five carrying the metafictional weight of the novel. The huge difference here is the interactions of Vonnegut, the real author, with his character, Trout, by the author's actual identity. Kurt Vonnegut comes into the story visiting Midland City to talk to Kilgore Trout telling him of his being a fictional character in one of Vonnegut's books and promising a great success in his later fictional life.

The fictional setting in which chemical compositions control the human behaviours of the protagonist under the influence of another fictional character deal directly with Vonnegut's intention to deconstruct " $[t]$ he things other people have put into [his] head, at any rate", things that "do not fit together nicely, are often useless and ugly, are out of proportion with one another" (Vonnegut, 1973, p. 7). Breakfast of Champions aims to change what other novels have already revealed of the society we live in and the culture we have been persuaded to accept as persistent standards to live by. It happens through the portrayal of the real construction of the American culture as well as that of the novel.

\section{CULTURAL CONSTRUCTION OR GRAND NARRATIVES}

Religion, history, and truth are the major grand narratives of American culture and Vonnegut tries to shed light on their nature in each part of his metafictional trilogy. Bokononism, the fictional religion of the novel Cat's Cradle, proposes an alternative to the existing religions by exposing its status as an artificial moral institution. It is a religion that honestly declares its base on 'foma', harmless lies, 
by which it fulfils some essential needs of the followers. The constructed nature of the creative religion, its fallibility in a fictional setting, allows it to be tested through a narrative that expresses its constructedness. Bokononist's religious text has an ever-changing capacity which stands against the autonomous state of earthly religions, as expressed in the novel - "there is no such thing as a completed copy" (Vonnegut, 1963, p. 124). Demonstrating a model religion that permits plural voices against the dogmatic discourses of systematized science unmasks the slips religious communities and their followers commit around the world. While the novel specifically focuses on Christianity, other religions share equal criticism in their claiming for ultimate truth against the provisional truths of Vonnegut proposed by the metafictional tone of the novel.

Slaughterhouse Five, the fictional self-conscious account of a World War II air raid which Vonnegut calls a massacre comes to change the interpretation of the concept of history as a grand narrative of the human culture. A sincere attempt to fictionalize a personal report of an unpleasant experience of the past may be simply called history against documentary, archived histories. Jesus de Castro in his essay The Narrative Function of Kilgore Trout and His Fictional Works in Slaughterhouse Five explains that the novel follows a dialectic and interdiscoursive process that "fictionalizes history while 'factualizing' what is fictional, by means of the formal linking of history and fiction through the common denominators of intertextuality and narrativity" (Vonnegut, 1969, p. 115). The fictionalized history in the novel enriches "the self-conscious dimension of history" (Vonnegut, 1969, p. 3), in the words of Linda Hutcheon, to display a multi-dimensional portrait of what we know as history. In Slaughterhouse Five Vonnegut, as a reporter of history, enacts a worldly grounding in a twofold practice. On the one hand, he emerges in his novel to bear a resemblance to an autobiography; on the other hand his novel shi$\mathrm{fts}$ frequently between fictional and fantastic texts to question the authority of the same grounding he has already constructed. Vonnegut's metafictional exposure of history provides lenses that detect various angles of history hidden as a result of established ruling authorities known as grand narratives.

Vonnegut's Dresden novel gives readers a metahistorical vision of a forgotten massacre like a bead on the string of other historical massacres the way Tralfamadorians, imaginative creatures from outer space, could look at the stretch of Rocky Mountains. Such a look may decode the secrets of everyday history. People are confused of as a result of blurring the barriers created by the ruling discourses of our society.

Breakfast of Champions, finally, is a call for rebirth when Vonnegut claims in his preface that he must make his head as empty as it was when he "was born onto this damaged planet fifty years ago" (Vonnegut, 1973, p. 5). It is in fact an appeal to all his readers to review their understanding of the world fundamentally. Vonnegut's direct intrusion in the novel both as a character and the author shows his impatient state in creating another metafiction that aims to challenge in a previously examined way. It mocks the boundaries between fact and fiction to work like a clarion in front of all institutional, organized realities of the world known as truth. Here Vonnegut comes to conclude his metafictiona quests and say that all so-called realities of the world - not only religion and history, but also reason, ob- 
jectivity, and even moralities - are under the effects of some totalizing discourses. This is the harshest way of portraying the deficiencies of the American culture that is shown to all as the ideal model of a New World.

\section{CONCLUSION}

Among many critics who studied the works and ideas of Vonnegut Jerome Klinkowitz summarizes him in brief: "Vonnegut's real intent is to reorder our perception of the world, to revalue our basis for meaning" (Klinkowitz, 1980, p. 51). Our basis for meaning may be reordered only when we acquire a good awareness of their nature, leading to an inclusive scheme that enables us to perceive hidden aspects in the complex discourses of a culture. Vonnegut's metafiction, humbly, carries out this function by an analogous study of such discourses in self-conscious novels. The unbiased, charming atmosphere of literature may affect people more profoundly than any theoretical discussion held by philosophers and social scientist whose main focus is to make people only understand things in the absence of pleasure. Vonnegut's metafiction unclothes the baffling king of culture to portray the deficiencies through a Horatian mixture of understanding and pleasure. The pleasant mixture of literature may decode many lockers.

\section{REFERENCES}

Allen, W. R., (ed.) (1993). Conversations with Kurt Vonnegut. Jackson: University of Mississippi.

De Castro, J. L. (1994). The Narrative Function of Kilgore Trout and His Fictional Works in Slaughterhouse-Five. Revista Alicantina de Estudios Ingleses, 7, 115-22.

Forrest, T. (1973). Necessary artifice: Form and Theory in the Poetry of Tel Quel. Language and Style, 6, 3-26.

Harper, D. (2001). Online Etymology Dictionary. Retrieved April, 28, 2013, from http:/ / www.etymonline. com/index. php?term=culture

Hutcheon, L. (1980). Narcissistic Narrative: The Metafictional Paradox. Waterloo: Wilfrid Laurier University Press.

Hutcheon, L. (1989). Historiographic Metafiction Parody and the Intertextuality of History. In: P. O'Donnell, \& C. Robert (eds.). Intertextuality and Contemporary American Fiction (pp. 3-32). Baltimore: Johns Hopkins University Press.

Jarvis, C. (2009). The Vietnamization of World War II in Slaughterhouse-Five and Gravity's Rainbow. In: H. Bloom (ed.). Kurt Vonnegut's Slaughterhouse-five. New York: Infobase Publishing.

Klinkowitz, J. (1980). The American 1960s: Imaginative Acts in a Decade of Change-r. Ames: Iowa State University Press.

Levine, Donald N. (1971) Introduction, in G. Simmel, On Individuality and Social Forms. Selected Writings. Chicago and London: The University of Chicago Press.

Von Knuth, Th. (2010). Forms and Functions of Metafiction. Retrieved February, 2, 2005, from http:// www.grin.com/e-book/46531/forms-and-functions-of-metafiction

Vonnegut, K. (1963). Cat's Cradle. New York: Dell Publishing Co.

Vonnegut, K. (1969). Slaughterhouse-Five. New York: Dell.

Vonnegut, K. (1973). Breakfast of Champions. New York: Rosetta Books.

Waugh, P. (1984). Metafiction: The Theory and Practice of Self-conscious Fiction. London: Methuen. 